Volume 4 Nomor 2, Juli-Desember 2020: hlm. 81-94.

Fakultas Hukum, Universitas Lampung,

Bandar Lampung, Lampung, Indonesia.

E-ISSN: 2598-3105 P-ISSN: 2723-2581

http://jurnal.fh.unila.ac.id/index.php/cepalo

\title{
PERUBAHAN WILAYAH LAUT ZONA EKONOMI EKSLUSIF RUSIA DI LAUT HITAM PASCA ANEKSASI KRIMEA
}

\section{THE CHANGES OF RUSSIAN EXCLUSIVE ECONOMIC ZONE IN THE BLACK SEA AFTER THE ANEXATION OF CRIMEA}

\section{Bertoni Dean Simamora ${ }^{1}$, Joko Setiyono²}

${ }^{1}$ Fakultas Hukum, Universitas Diponegoro, Email: bertoni.simamora@gmail.com

${ }^{2}$ Fakultas Hukum Universitas Diponegoro, Email: jokosetiyono61@yahoo.com

Submitted: May 22, 2020; Reviewed: June 11, 2020; Accepted: June 29, 2020

DOI: $10.25041 /$ cepalo.v4no2.2079

\begin{abstract}
Abstrak
Rusia merupakan negara yang memiliki wilayah yang sangat luas dan sumber daya yang banyak. Februari 2014 Rusia melakukan aksi aneksasi di Semenanjung Krimea. Konsekuensi anekasi Krimea oleh Rusia melampaui kekhawatiran akan kedaulatan tanah dan jauh ke perairan Laut Hitam terutama yang berhubungan dengan laut Zona Ekonomi Eksklusif. Pada Zona Ekonomi Eksklusif, negara pantai memiliki hak untuk mengatur segala kegiatan eksplorasi dan juga eksploitasi sumber daya alam di permukaan laut, di dasar laut dan juga di bawah laut, serta mengadakan penelitian sumber daya hayati maupun sumber daya laut yang lainnya. Timbul permasalahan yaitu: bagaimana perubahan wilayah laut zona ekonomi ekslusif Rusia di Laut Hitam Pasca Aneksasi Krimea dan bagaimana dampak bertambahnya wilayah laut zona ekonomi ekslusif Rusia di laut hitam akibat aneksasi Krimea terhadap Ukraina. Penelitian ini bertujuan untuk melihat mengenai perubahan wilayah laut zona ekonomi eksklusif Rusia di Laut Hitam pasca aneksasi Krimea serta dampaknya terhadap Ukraina. Metode penelitian yang digunakan di dalam penelitian ini adalah Metode penelititan normatif yang bersifat kualitatif dalam penelitian terhadap bahan pustaka yang merupakan data dasar yang dalam ilmu pengetahuan digolongkan sebagai data sekunder yang bertumpu kepada alat pengumpulan data berupa studi kepustakaan atau studi dokumen atas permasalahan perubahan wilayah laut zona ekonomi eksklusif Rusia di laut Hitam pasca aneksasi Krimea. Hasil penelitian menunjukkan bahwa erubahan wilayah laut Rusia di laut hitam yang sangat signifikan tentunya juga akan memberi keuntungan yang sangat besar dalam pemanfaatan zona ekonomi ekslusif yang baru ini bagi Rusia. Mahakamah Internasional (International Court of Justice) dapat menyelesaikan konflik antara Ukraina dan Rusia. UNCLOS 1982 dapat digunakan sebagai panduan dalam penyelesaian masalah mengingat Rusia dan Ukraina. Bagi Ukraina, Kebutuhan Ekonomi dalam bidang ekonomi seperti Perikanan, Kebutuhan barang tambang, arus lalu lintas laut, kebutuhan Angkatan perang Ukraina, dan jalur perdagangan menjadi dampak di aneksasinya Krimea oleh Rusia.
\end{abstract}


Kata Kunci: Aneksasi, Laut, Krimea, ZEE.

\section{Abstract}

Russia is a country that has a very large area and a lot of resources. February 2014 Russia carried out an act of annexation on the Crimean Peninsula. The consequences of the annexation of Crimea by Russia go beyond concerns over land sovereignty and deep into the waters of the Black Sea especially those associated with the Sea of the Exclusive Economic Zone. In the Exclusive Economic Zone, the coastal state has the right to regulate all exploration activities as well as exploitation of natural resources at sea level, on the seabed and also under the sea, as well as to conduct research on biological resources and other marine resources. Problems arise, namely: how the changes in the marine area of Russia's exclusive economic zone in the Black Sea after the annexation of Crimea and how the impact of the increasing sea area of Russia's exclusive economic zone in the black sea due to Crimea's annexation of Ukraine. This study aims to look at changes in the marine area of Russia's exclusive economic zone in the Black Sea after the annexation of Crimea and its impact on Ukraine. The research method used in this research is a qualitative normative research method in research of library materials which is basic data which in science is classified as secondary data which relies on data collection tools in the form of library studies or document studies on the problem of changes in the sea zone. Russia's exclusive economy on the Black sea following the annexation of Crimea. The results show that a very significant change in Russia's sea area in the Black Sea will certainly provide enormous benefits in the utilization of this new exclusive economic zone for Russia. The International Court of Justice can resolve conflicts between Ukraine and Russia. UNCLOS 1982 can be used as a guide in solving problems considering Russia and Ukraine. For Ukraine, economic needs in the economic field such as fisheries, mineral needs, sea traffic flow, the needs of the Ukrainian army, and trade routes were the effects of Russia's annexation of Crimea.

Keywords: Annexation, Crimea, Sea, ZEE.

\section{A. Pendahuluan}

Rusia merupakan negara yang memiliki wilayah yang sangat luas dan sumber daya yang banyak. Dengan luasnya wilayah dan besarnya sumber daya yang ada menjadikan Rusia sebagai salah satu negara adi daya di dunia. Wilayah laut Rusia dapat dilihat terbentang dari laut artik, laut baltik, laut hitam, laut kaspian, hingga laut pasifik yang mengintari wilayahnya ${ }^{1}$.

Februari 2014, terjadi sebuah krisis internasional di semenanjung Krimea. Rusia melakukan aksi aneksasi di Semenanjung Krimea. Republik Otonom Krimea dan Kota Sevastopol secara mengejutkan memilih untuk bergabung ke Federasi Rusia. Krisis internasional ini melibatkan Rusia dan Ukraina dan pada akhirnya Ukraina kehilangan kontrol atas wilayah Krimea. Pada akhirnya secara de facto, Rusia menguasai wilayah Krimea meskipun keberadaannya belum diakui PBB. ${ }^{2}$ Hal referendum yang diselenggarakan oleh parlemen Republik Otonom Krimea ditentang oleh Uni Eropa karena dipandang bertentangan dengan hukum internasional. Parlemen Krimea kemudian mendeklarasi kemerdekaannya dari Ukraina dan memutuskan untuk bergabung

\footnotetext{
${ }^{1}$ https://www.britannica.com/place/Russia, diakses pada tanggal 16 September 2020 pukul 12.59 WIB.

${ }^{2}$ Dengan dikeluarkannya Resolusi Majelis Umum Perserikatan Bangsa-Bangsa A/RES/68/262 yang menyatakan bahwa referendum yang dilaksanakan Republik Otonom Krimea tidak valid.
} 
ke Federasi Rusia pada tanggal 17 Maret 2014. Keesokan harinya pada tanggal 18 Maret 2014, Rusia dan Republik Krimea menandatangani kesepakatan untuk bergabungnya Republik Krimea dan Sevastopol ke dalam Federasi Rusia. Serupa dengan Uni Eropa, PPB juga mengeluarkan Resolusi Majelis Umum Perserikatan Bangsa-Bangsa A/RES/68/262 yang menyatakan bahwa referendum yang dilaksanakan Republik Krimea tidak valid dan bergabungnya Republik Krimea ke dalam Rusia adalah tindakan yang illegal. ${ }^{3}$

Konsekuensi anekasi Krimea oleh Rusia melampaui kekhawatiran akan kedaulatan tanah dan jauh ke perairan Laut Hitam. Rusia telah mulai membentuk kembali laut teritorialnya dan Zona Ekonomi Eksklusif (ZEE) sepanjang 200 mil di Laut Hitam utara, menempatkan Ukraina di negara yang bahkan lebih rentan secara ekonomi, militer, dan politik. Jika Krimea memiliki garis pantai lurus, penentuan garis perbatasan laut tidak akan rumit. Karena Krimea merupakan semenanjung dengan bentuk pantai yang sangat kompleks dan berbatasan dengan wilayah laut yang tertutup (Laut Azov), maka permasalahan antara Rusia dan Ukraina akan lebih kompleks.

Rezim Zona Ekonomi Ekslusif dipandang sebagai bagian dari hukum kebiasaan internasional dibanyak kasus judisial internasional dengan signifikasi bagian dari lautan dan samudera dunia dan lautan yang tidak tercangkup dari zona yurisdiksi maritim ini. ${ }^{4}$ Konvensi PBB tentang Hukum Laut (United Nations Convention on the Law of the Sea) selanjutnya disebut (UNCLOS) berisi persyaratan implisit yang menyatakan negara menyatakan Zona Ekonomi Eksklusif (ZEE) untuk membangun zona dan hak mereka untuk itu. ${ }^{5}$ Menurut Konvensi PBB tentang Hukum Laut (UNCLOS), Zona Ekonomi Eksklusif merupakan suatu zona yang terbentang selebar tidak lebih dari 200 mil laut yang dihitung dari garis pangkal ${ }^{6}$. Pada Zona Ekonomi Eksklusif, negara pantai memiliki hak berdaulat untuk mengatur segala kegiatan eksplorasi dan juga eksploitasi sumber daya alam di permukaan laut, di dasar laut dan juga di bawah laut, serta mengadakan penelitian sumber daya hayati maupun sumber daya laut yang lainnya. Dalam Zona Ekonomi Eksklusif yang panjangnya 200 mil ini, maka negara pantai mempunyai hak atas kekayaan alam yang ada di wilayah laut tersebut dan juga berhak menggunakan kebijakan hukumnya, kebebasan bernavigasi, terbang di atasnya ataupun melakukan penanaman kabel dan juga pipa-pipa. ${ }^{7}$

Berdasarkan uraian di atas, dapat diketahui bahwa aneksasi Krimea oleh Rusia meimbulkan permasalahan yang dapat menyebabkan bergesernya laut Zona Ekonomi Eksklusif Ukraina di laut hitam dan pada akhirnya diambil alih oleh Rusia. Bergesernya laut Zona Ekonomi Eksklusif Ukraina di laut hitam dapat menimbulkan masalah-masalah baru yang dapat menjadi dampak bagi Ukraina. Dengan adanya permasalahan ini maka negara-negara lain juga akan terdampak dan dapat menjalankan hubungan antara Ukraina dan Rusia dengan baik.

Dari latar belakang yang telah dipaparkan maka dapat dirumuskan permasalahan sebagai berikut; (1) bagaimana perubahan wilayah laut zona ekonomi ekslusif di Laut Hitam pasca aneksasi Krimea serta cara penyelesaiannya; (2) bagaimana dampak bertambahnya wilayah laut zona ekonomi ekslusif Rusia di laut hitam akibat aneksasi Krimea terhadap Ukraina. Tujuan dari penelitian ini agar dapat mengetahui wilayah laut zona ekonomi ekslusif Rusia di Laut Hitam Pasca Aneksasi Krimea serta dampak bertambahnya wilayah laut zona ekonomi ekslusif Rusia di laut hitam pasca aneksasi Krimea terhadap Ukraina.

\footnotetext{
${ }^{3} \mathrm{https} / / /$ undocs.org/en/A/RES/68/262, diakses pada tanggal 16 September 2020, pukul 22.03 WIB.

${ }^{4}$ Clive Schofield, "PARTING THE WAVES: CLAIMS TO MARITIME JURISDICTION AND THE DIVISION OF OCEAN SPACE", Penn St. JL \& International Affair 1, no 1 (2012): 40-58, 43

${ }^{5}$ Shani Friedman, "THE CONCEPT OF ENTITLEMENT TO AN EXCLUSIVE ECONOMIC ZONE AS REFLECTED IN INTERNATIONAL JUDICIAL DECISIONS", Israel Law Review 53, no. 1 (2020): 101-133, 101.

${ }^{6}$ Pasal 57 Konvensi Perserikatan Bangsa-Bangsa tentang Hukum Laut (UNCLOS).

${ }^{7}$ Pasal 56 Konvensi Perserikatan Bangsa-Bangsa tentang Hukum Laut (UNCLOS).
} 
Metode pendekatan yang digunakan dalam pembahasan mengenai perubahan wilayah laut zona ekonomi eksklusif Rusia di laut Hitam pasca aneksasi Krimea ini adalah dengan menggunakan metode pendekatan doktrinal atau yuridis normatif yang bersifat kualitatif ${ }^{8}$. Metode penelititan normatif yang bersifat kualitatif dalam penelitian ini adalah terhadap bahan pustaka yang merupakan data dasar yang dalam ilmu pengetahuan digolongkan sebagai data sekunder ${ }^{9}$ yang bertumpu kepada alat pengumpulan data berupa studi kepustakaan atau studi dokumen. Hal ini dilakukan karena penulis mengkaji permasalahan perubahan wilayah laut zona ekonomi eksklusif Rusia di laut Hitam pasca aneksasi Krimea dari hasil penelitian dan artikel yang membahas berkaitan dengan penelitian yang ingin dikaji oleh penulis. Menurut Lexy J. Moleong, metode pengumpulan data pada penelitian ini dengan menganalisis fenomena, mengidentifikasi peraturan, mendeskriptifkan kata-kata dari bahan hasil penelitian (karya ilmiah), dan sumber bahan hukum lainnya yang memiliki relevansi pada pembahasan penelitian yang diangkat. ${ }^{10}$

\section{B. Pembahasan}

\section{Perubahan Wilayah Laut Zona Ekonomi Ekslusif di Laut Hitam Pasca Aneksasi Krimea serta Cara Penyelesaiannya}

\section{a. Kepentingan Rusia Di Laut Hitam}

Wilayah Laut Hitam yang ditetapkan sebagai negara pesisir Bulgaria, Rumania, Ukraina, Rusia, Georgia, dan Turki memiliki signifikansi strategis yang tinggi. Pada tanggal 25 Desember 1991, setelah Mikhail Gorbachev mengundurkan diri sebagai pemimpin Uni Soviet, Rusia yang dipimpin oleh Boris Yeltsin menyatakan diri sebagai negara yang independen dan mensuksesi Uni Soviet di PBB. Rusia sebagai salah satu negara terbesar di dunia yang memiliki kekuatan baik sumber daya alam, sumber daya manusia maupun kekuatan angkatan perang yang besar menjelma menjadi kekuatan baru di Eropa Timur. Kepentingan strategis Rusia di kawasan Laut Hitam, terutama dalam hal energi dan kehadiran militer, konflik dengan kepentingan Ukraina, Turki, Uni Eropa, dan Amerika Serikat, dengan yang lainnya. Aneksasi Krimea oleh Rusia diklaim sebagai keputusan strategis, terlepas dari dampak buruk rezim pasca-Perang Dingin. ${ }^{11}$

Rusia memiliki beberapa laut yang mengintari wilayahnya. Beberapa laut yang mengintari Rusia seperti laut Artik, Laut Okhotsk, Laut Baltik, Laut Jepang, Laut Kaspia dan yang dalam pembahasan ini adalah Laut Azov dan Laut Hitam. ${ }^{12}$ Rusia memiliki kepentingan tersendiri di Laut Hitam. Penguasaan wilayah Laut Hitam merupakan hal yang signifikan bagi Rusia karena Laut Hitam merupakan arteri yang menghubungkan Negara Eropa Timur ke perdagangan dunia. Laut Hitam juga memiliki beberapa sumber daya seperti ikan laut dan komponen kimia hidrogen sulfide. ${ }^{13}$ Laut Hitam memberi Rusia salah satu dari dua sarana akses langsung ke "perairan hangat" (yang lainnya adalah pantai Pasifik Timur Jauh Rusia) meskipun dibatasi oleh kontrol

\footnotetext{
${ }^{8}$ Peter M Marzuki, Penelitian Hukum (Jakarta: Kencana Prenada Media Group, 2015), 35.

${ }^{9}$ Soerjono Soekanto dan Sri Mamudji, Penelitian Hukum Normatif (Jakarta: Raja Grafindo Persada, 2004), 24.

${ }^{10}$ Lexy J Moleong, Metodologi Penelitian Kualitati Edisi Revisi (Bandung: Remaja Rosdakarya, 2011), 3.

- ${ }^{11}$ Steven Blockmans, "CRIMEA AND THE QUEST FOR ENERGY AND MILITARY HEGEMONY IN THE BLACK SEA REGION: GOVERNANCE GAP IN A CONTESTED GEOSTRATEGIC ZONE", Southeast European and Black Sea Studies 15, no. 2 (2015): 179-189, 179, DOI: 10.1080/14683857.2015.1060016.

${ }^{12}$ Encyclopædia Britannica, "Russia", Loc. Cit

${ }^{13}$ https://www.britannica.com/place/Black-Sea/Economic-aspects, Diakses pada tanggal 22 Juli 2020, pukul 13.59 WIB.
} 
Turki atas Selat Bosphorus. Rusia secara tradisional memberi penekanan pada kebijakan luar negerinya pada pemeliharaan "zona penyangga" antara Rusia dan musuh potensial. Karena itu, mungkin perlu dipahami keprihatinan Rusia bahwa Ukraina sedang berdialog dengan aliansi militer yang dianggap Rusia sebagai ancaman eksistensial seperti Uni Eropa dan Amerika Serikat sebagai musuh potensial. ${ }^{14}$

Rusia mempertahankan kehadiran militer yang signifikan di wilayah Laut Hitam yang terkonsentrasi di Distrik Militer Kaukasus Utara dan Armada Laut Hitam dengan pasukan tambahan yang berbasis di Armenia. Distrik Militer Kaukasus Utara mencakup komponen Pasukan Darat substansial yang terutama berbasis di Ossetia Utara, Chechnya dan Dagestan dan komponen Pasukan Khusus yang kuat sekitar empat ribu personel. ${ }^{15}$ Wilayah Laut Hitam juga merupakan komponen integral dari strategi geo-ekonomi Rusia karena berupaya untuk mengamankan monopoli atas ekspor minyak dan gas dari Cekungan Kaspia dan Asia Tengah ke Eropa. Dari perspektif ini, elemen inti dari strategi besar Rusia tetap disibukkan dengan konfrontasi dan paksaan baik oleh militer, ekonomi atau cara lain dan kebijakannya terhadap negara-negara kawasan Laut Hitam umumnya mencerminkan hal ini, terutama berkaitan dengan negara-negara yang mencari hubungan lebih dekat dengan komunitas Euro-Atlantik. ${ }^{16}$ Wilayah Laut Hitam secara strategis vital bagi Eropa untuk mengembangkan keamanan energi. Baillie mengatakan bahwa sekitar setengah dari permintaan energi Eropa dipenuhi oleh impor yang 25 persennya diimpor dari Rusia menunjukkan pentingnya mengembangkan keamanan energi melalui keragaman sumber (minyak, gas, nuklir, dan sebagainya) dan persediaan lainnya. ${ }^{17}$

Banyak negara-negara di dunia menjaga proses pengendalian senjata tetap hidup atau setidaknya hanya tidak ingin mengorbankan hubungan dengan Rusia. Rusia tidak menunjukkan kecenderungan untuk tidak melepaskan taktik pengancaman dengan kekuatan bersenjata dan pada kenyataannya telah meningkatkan retorikanya bahwa ia akan menggunakan senjata nuklir terlebih dahulu jika merasa terancam. Mengomentari laporan kepatuhan kontrol senjata Departemen Luar Negeri setahun yang lalu, Anggota Kongres Mac Thornberry, ketua Komite Angkatan Bersenjata kongres Amerika Serikat, menyatakan bahwa pengembangan platform nuklir jarak menengah Rusia dirancang untuk menjaga kepentingan Amerika Serikat dalam risiko dan mengaktifkan kebijakan ekspansionis Vladimir Puti. ${ }^{18}$ Dengan demikian dapat diketahui bahwa ada kepentingan yang mendasar dari Rusia untuk melakukan ekspansi demi memunculkan Rusia sebagai negara adidaya yang lebih besar lagi pengaruhnya di Eropa dengan adanya penggunaan senjata nuklir sebagai ancaman dan untuk memperluas wilayahnya dan dalam hal ini adalah kehadiran militer Rusia yang lebih besar di Krimea dan di sekitar Laut Hitam.

\section{b. Wilayah Laut Rusia di Laut Hitam Pasca Aneksasi Krimea}

Kovensi PBB (Konvensi Jenewa 1958) tentang Hukum Laut mengatur rezim baru tentang Zona Ekonomi Eksklusif (ZEE) yang lebarnya 200 mil laut dari garis pangkal. Menurut Tahar $^{19}$,

\footnotetext{
14 James Bosbotinis, "ASSESSING THE STRATEGIC IMPORTANCE OF THE BLACK SEA REGION", Romanian J. Eur. Aff 10, (2010): 1-22, 5.

${ }^{15}$ Denis Trifanov, "RUSSIA BOOSTS COUNTERINSURGENCY EFFORTS IN NORTH CAUCASUS", Jane's Intelligence Review, 18, no. 2 (2006): 1-98, 35

${ }^{16}$ James Bosbotinis, Loc. Cit., 14

17 R. Baillie, "EUROPE SEEKS SECURE ENERGY SUPPLY AS RUSSIA TURNS UP HEAT", Jane's Intelligence Review 18, no. 12 (2006): 1-10, 7.

${ }_{18}^{18}$ Mark B. Schneider, "RUSSIA CHEATS", Air Force Magazine 99, no. 7 (2016): 38-42, 38-39.

${ }^{19}$ Abdul Muthalib Tahar, Zona-Zona Maritim Berdasarkan Konvensi Hukum Laut 1982 dan Perkembangan Hukum Laut Indonesia (Lampung: Universitas Lampung, 2011), 5-6.
} 
secara umum, fungsi atau manfaat laut adalah: sebagai sumber kekayaan alam (meliputi di daerah perairan dan daerah dasar laut dan tanah di bawahnya berupa sumber kekayaan hayati dan sumber kekayaan non hayati), sebagai sarana lalu lintas kapal dan transportasi (Disahkannya Konvensi Hukum Laut 1982 mengatur hak lintas damai, hak lintas transit dan hak lintas alur kepulauan), sebagai sarana kepelabuhanan (Pelabuhan sebagai sarana transportasi kapal, sumber pendapatan negara), sebagai sarana rekreasi (Pantai sebagai sarana rekreasi dan wisata bahari), Sebagai sarana untuk memasang kabel dan pipa bawah laut (Penyaluran tenaga listrik, saluran telepon, saluran air bersih, gas atau minyak), sebagai sarana untuk melakukan penelitian ilmiah kelautan (Pengembangan ilmu pengetahuan dengan tujuan damai), sebagai sarana untuk membuang limbah (dalam arti negatif yang berhubungan dengan perusakan laut), sebagai sarana pertempuran dan menundukkan lawan (menyerang negara lain atau musuh dan unjuk kekuatan).

Konvensi hukum laut internasional, yang diselenggarakan pada tanggal 10 Desember 1982 di Montego Bay, Jamaika pada saat suksesi Rusia dari Uni Soviet belum diratifikasi oleh Rusia dan baru diratifikasi pada tanggal 12 Maret $1997 .{ }^{20}$ Dengan diratifikasinya Konvensi Hukum Laut Internasional ini ke dalam hukum Rusia menjadikan Rusia tunduk kepada keberlakuan dan berlakunya konvensi ini.

Aneksasi Krimea oleh Rusia pada tahun 2014, memiliki beberapa dimensi zona abu-abu maritim yang penting. Rusia sangat ingin memastikan bahwa Angkatan Laut Ukraina tidak dapat melakukan intervensi. Pada tahun 2018, status Laut Azov, yang dibagi Ukraina dan Rusia, telah menciptakan ketegangan baru dan kemungkinan tindakan lebih lanjut zona abu-abu Rusia. Pada bulan Maret, pihak pemerintah Ukraina menangkap kapal penangkap ikan Rusia yang mereka klaim beroperasi di laut teritorial mereka, sementara pada bulan berikutnya, kapal keruk Rusia yang berlabuh di Odessa ditahan dengan alasan bahwa kapal itu secara ilegal bekerja di Krimea. Pihak berwenang Rusia menanggapi langkah-langkah ini dengan menyarankan bahwa Rusia harus memblokir Selat Kerch, yaitu satu-satunya akses dari Laut Hitam ke Laut Azov ke kapal angkatan laut dan kapal dagang Ukraina. ${ }^{21}$ Menurut Departemen Luar Negeri AS, Rusia memulai kampanye sistematis untuk mengganggu pengiriman dagangan pada April 2018. Pada Agustus, ratusan kapal dagang telah tertunda dan 16 dicegah langsung melanjutkan perjalanan mereka ke pelabuhan Ukraina. ${ }^{22}$ Krimea, yang beberapa abad sebelumnya memainkan peran kunci dalam perdagangan domestik dan luar negeri negara itu di wilayah Azov-Laut Hitam, membutuhkan kebangkitan posisinya dalam realitas modern Rusia. ${ }^{23}$

Efektivitas laut zona ekonomi eksklusif didasarkan pada sifat integratif dan mekanisme bawaan untuk menghitung dan mendamaikan kepentingan berbagai pemangku kepentingan. Pada saat yang sama, sifatnya membuat model ini sangat sensitif terhadap keamanan nasional,

\footnotetext{
${ }^{20}$ United Nation, Buletin Law of the Sea. Division for Ocean Affairs and the Law of the Sea Office of Legal Affairs (New York:United Nation, 2004), 7

21 https://jamestown.org/program/russian-navy-preparing-to-bottle-up-ukrainian-shipping-in-sea-of-azov, diakses pada tanggal 22 Juli 2020 pukul 14.42 WIB.

${ }^{22} \mathrm{https}: / /$ www.state.gov/r/pa/prs/ps/2018/08/285578.htm, diakses pada tanggal 22 Juli 2020, pukul 15.31 WIB, Lihat juga James Goldrick, Grey Zone Operations and he Maritime Domain, Australian Strategic Policy Institute (Australia: Barton ACT, 2018), 14.

${ }^{23}$ Natalia D. Borshchik, Elena V. Latysheva, Dmitrij A. Prohorov, "CUSTOMS, BORDER AND QUARANTINE CONTROL BODIES OF THE CRIMEAN PENINSULA IN THE LATE 18TH - FIRST HALF OF THE 19TH CENTURY: REGULATORY FRAMEWORK AND PERSONNEL STRUCTURE", Bylye Gody 54, no. 4 (2019): $1506-1513,1506$.
} 
mengingat konflik yang ada atau berpotensi terjadi, karena dalam situasi ini kemampuan negara untuk menggunakan kepentingannya sendiri, termasuk kekuatan akan selalu diutamakan. ${ }^{24}$

Berikut adalah beberapa gambaran mengenai wilayah laut Ukraina dan Rusia sebelum dan sesudah aneksasi Krimea:

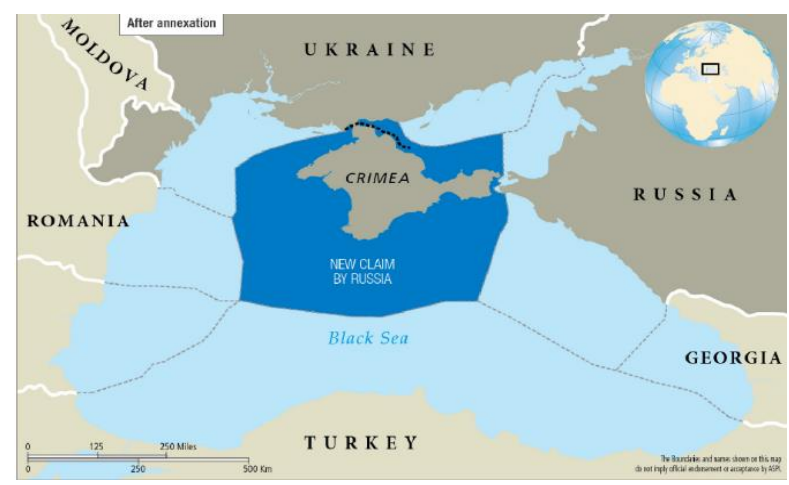

Gambar 1. Bagaimana Aneksasi Krimea merubah ZEE Rusia

Dengan diperlihatkannya Gambar 1, dapat dilihat Rusia mendapat keuntungan yang sangat besar dengan adanya aneksasi Krimea. Berubahan wilayah Laut Rusia di Laut Hitam yang sangat signifikan tentunya juga akan memberi keuntungan yang sangat besar dalam pemanfaatan Zona Ekonomi Ekslusif yang baru ini bagi Rusia. Bagi Rusia, pentingnya wilayah Laut Hitam semakin ditingkatkan karena posisinya sebagai pusat ekonomi penting, khususnya, berkaitan dengan energi dan transportasi. Pengembangan sumber daya hidrokarbon di Laut Kaspia dan Asia Tengah adalah minat utama bagi Eropa untuk mempromosikan keamanan energi. ${ }^{25}$

Gambar 2. Klaim wilayah laut baru Rusia setelah aneksasi Krimea ${ }^{26}$

24 Borys Kormych, Tetiana Averochkina, Vitalii Gaverskyi, "THE PUBLIC ADMINISTRATION OF TERRITORIAL SEAS: UKRAINIAN CASE", Int Environ Agreements 49, no. 6 (2020): 577-595, 577-578.

${ }^{25}$ James Bosbotinis, Op. Cit., 18.

${ }^{26}$ James Goldrick, "Grey Zone Operations and The Maritime Domain", Australian Strategic Policy Institute (Australia: Barton ACT, 2018), 14. 


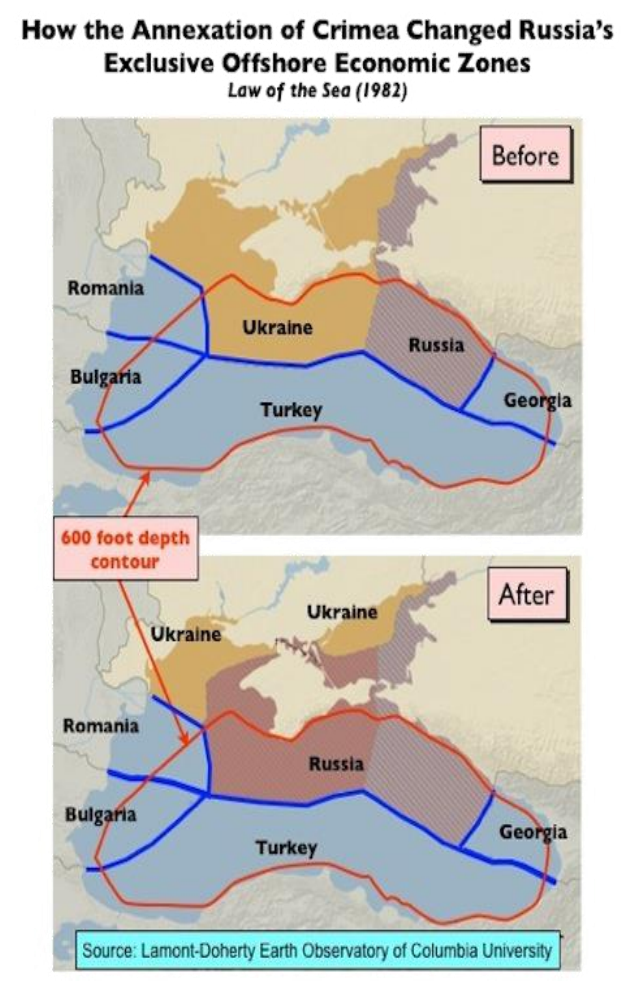

Dapat dilihat dari Gambar 2, bahwa porsi laut yang akan dimiliki Rusia dari wilayah Krimea sendiri sudah akan menjadi keuntungan Rusia yang sangat besar dalam hal bidang ekonomi, politik, dan keamanan bagi Rusia. Ada berbagai cara di mana Rusia dapat digunakan untuk memperluas pengaruh regionalnya, seperti ekspor energi dan hubungan perdagangan, serta peran Rusia sebagai wilayah untuk memberikan pengaruh politik dan ekonomi di wilayahnya. ${ }^{27}$ Salah satu alasan utama aneksasi Krimea oleh Rusia adalah nilai strategis Krimea bagi pangkalan Armada Laut Hitam Rusia. ${ }^{28}$

Ada beberapa Perjanjian Bilateral dengan Ukraina yang dilanggar Rusia, diantaranya adalah Perjanjian Perizinan Akses ke Black Sea (Agreements Permitting Access to the Black Sea) dan Traktat Persahabatan Rusia-Ukraina (The Friendship Treaty Rusia-Ukraine). Tidak hanya itu, ada beberapa prinsip hukum internasional yang Rusia langgar. Ini adalah beberapa hukum internasional yang telah dilanggar Rusia: prinsip untuk tidak intervensi dalam urusan negara lain (Customary Principle of Non-Intervention), menghormati kemerdekaan dan integritas wilayah negara, dan prinsip non-pengakuan atas wilayah yang diambil alih secara ilegal (The Principle of Non-Recognition of Territorial Acquisition). ${ }^{29}$

\footnotetext{
${ }^{27}$ Indriana Kartini, "ANEKSASI RUSIA DI KRIMEA DAN KONSEKUENSINYA BAGI UKRAINA", Jurnal Penelitian Politik 11, no. 2 (2016): 27-41, 38, DOI: 10.14203/jpp.v11i2.199.

${ }^{28}$ Jeffrey Mankoff, "RUSSIA'S LATEST LAND GRAB: HOW PUTIN WON CRIMEA AND LOST UKRAINE", Foreign Affairs 93, no. 3 (2014): 60-68, 63.

29 Madeline Olliver, "AN INTERNATIONAL LEGAL ANALYSIS OF RUSSIA'S INTERVENTION IN UKRAINE”, Disertasi Bachelor of Law, the University of Otago, New Zaeland, (2015), 17-27
} 


\section{c. Aneksasi Dalam Hukum Internasional dan Penyelesaian Sengketa ZEE}

Pasal 1 Konvensi Motevideo 1933 mengenai hak-hak dan kewajiban-kewajiban negara, mengatur bahwa salah satu unsur negara adalah wilayah. ${ }^{30}$ Konsep wilayah negara memberikan prinsip non-intervensi dalam persoalan yang mencakup yurisdiksi domestik dan prinsip untuk menghormati integritas wilayah negara lain ${ }^{31}$. Dalam perkembangannya, seringkali terjadi konflik konflik yang bersumberkan pada masalah batas wilayah negara terutama dalam pembahasan ini adalah Laut Zona Ekonomi Ekslusif.

Aneksasi adalah metode untuk memperoleh kedaulatan teritorial (dipaksakan) yang diterapkan oleh dua jenis kondisi:

a) Apabila wilayah yang dianeksasi telah ditundukkan oleh negara yang menganeksasi tanpa adanya pengumuman kehendak;

b) Apabila wilayah yang dianeksasi dalam kedudukan yang benar-benar berada di bawah negara yang menganeksasi pada waktu diumumkannya kehendak aneksasi oleh negara tersebut.

Penaklukan wilayah seperti (a) tidaklah cukup hanya mendasar untuk mendapatkan hak. Selain itu, persyaratan aneksasi harus dinyatakan dalam bentuk nota yang dikirimkan secara resmi ke semua negara yang berkepentingan. Kedaulatan atas wilayah yang ditaklukkan oleh negara-negara penakluk tidak akan diperoleh kecuali mereka secara terbuka bersedia menambahkannya. Aneksasi yang dilakukan oleh satu negara terhadap negara lain atau sebagai akibat dari agresi brutal yang melanggar Piagam PBB dan tidak dapat diterima oleh negara lain.$^{32}$ Penaklukan wilayah darat yang berbatasan dengan laut juga dapat mempengaruhi wilayah laut sesuai dengan UNCLOS 1982.

PBB Sebagai Organisasi Internasional dalam menyelesaikan konflik antara Ukraina dan Rusia sudah mencoba mengeluarkan resolusi yang berkaitan dengan hal ini adalah Resolusi Majelis Umum Perserikatan Bangsa-Bangsa A/RES/68/262 tentang Integritas Wilayah Ukraina. Resolusi yang dikeluarkan PBB pertama kali dalam konflik Rusia-Ukraina adalah resolusi tentang integritas wilayah Ukraina yang telah dilanggar oleh Rusia dengan cara menganeksasi wilayah Krimea tersebut dari Ukraina. Sejak berdirinya, PBB memiliki tujuan dan prinsip dasar yang dianut oleh masing-masing negara anggota PBB. Prinsip dasar tersebut salah satunya adalah larangan bagi masing-masing negara untuk menggunakan militer untuk mengancam kedaulatan wilayah negara lain. Pasal 2 ayat 4 Piagam PBB menegaskan tentang kedaulatan wilayah negara dan larangan negara lain untuk menggunakan militer untuk melanggar teritorial wilayah negara lain.

Mahakamah Internasional (International Court of Justice) merupakan lembaga peradilan dibawah Perserikatan Bangsa-Bangsa yang mengadili sengketa internasional yang melibatkan negara. Sengketa internasional dibedakan menjadi dua yakni sengketa hukum yang merupakan sengketa yang tuntutannya berlandaskan perjanjian internasional atau yang telah diakui dalam hukum internasional. Dalam penyelesaian sengketa internasional negara diberikan kebebasan untuk memilih prosedur penyelesaian. Hal ini sesuai dengan Pasal 33 Piagam PBB bahwa dalam sengketa internasional, para pihak dapat memilih penyelesaian sengketanya baik melalui jalur non peradilan maupun melalui jalur peradilan. Negosiasi bukanlah cara terbaik untuk

\footnotetext{
${ }^{30}$ Jawahir Thontowi, Hukum Internasional Kontemporer (Bandung: Refika Aditama, 2006), 177.

${ }^{31}$ Malcolm N Shaw, International Law, (Cambridge: Cambridge University Press, 1997), 330.

32 Adijaya Yusuf, "PENERAPAN PRINSIP PENDUDUKAN EFEKTIF DALAM PEROLEHAN WILAYAH: PERSPEKTIF HUKUM INTERNASIONAL", Jurnal Hukum \& Pembangunan 33, no. 1 (2017): 1-15, 16-17, DOI: 10.21143/jhp.vol33.no1.1361.
} 
menyelesaikan sengketa ${ }^{33}$ maka dari itu terdapat proses penyelesaian sengketa melalui Mahkamah Internasional.

Menurut UNCLOS 1982, dalam kasus klaim maritim yang tumpang tindih, diperlukan demarkasi batas laut, baik melalui negosiasi atau dengan partisipasi negara terkait melalui pihak ketiga lainnya seperti International Court of Justice (ICJ). Metode ini terserah masing-masing pihak untuk memilih cara menyelesaikan sengketa. Ketentuan Konvensi memuat dua ketentuan terkait dengan batas laut (delimitasi) antara negara yang saling berhadapan (opposite) atau bersampingan (adjacent) yaitu landas kontinen (pasal 83), dan zona ekonomi ekslusif (pasal 74) yaitu:

1) Penentuan batas (delimitation) zona ekonomi ekslusif antara negara-negara dengan pantai yang berhadapan atau berdampingan harus dilakukan dengan perjanjian berdasarkan hukum internasional atas dasar penyelesaian yang adil (equitable solution) (pasal 74).

2) Penentuan batas landas kontinen sama seperti yang berlaku untuk zona ekonomi ekslusif (pasal 83).

Menurut UNCLOS, Proses demarkasi landas kontinen mengacu pada Pasal 83 yang membutuhkan penyelesaian yang adil (Ayat 1). Untuk mencapai solusi yang adil, kedua negara perlu kreatif agar memiliki tim negosiasi yang cukup potensial. Utamanya, 'adil' tidak selalu sama jarak atau equidistance. ${ }^{34}$

\section{Dampak Bertambahnya Wilayah Laut Zona Ekonomi Ekslusif Rusia di Laut Hitam Akibat Aneksasi Krimea Terhadap Ukraina}

Tatanan internasional telah memasuki era baru yang ditandai dengan perubahan dramatis, baik dari segi struktur maupun proses. Dalam dunia non-kutub yang terus berkembang ini. Munculnya Laut Hitam sebagai suatu wilayah dan sebagai pusat geopolitik tidak dapat disangkal namun masalah yang dihadapi banyak, kompleks dan menantang. ${ }^{35}$ Sistem rezim hukum laut teritorial (juga zona ekonomi eksklusif) negara-negara modern, termasuk Ukraina, dibentuk sebagai aturan rezim yang bersifat hukum administratif. Norma perundang-undangan nasional sangat dipengaruhi oleh (dan tidak dapat bertentangan) standar internasional yang ditetapkan oleh UNCLOS tahun 1982 dan perjanjian internasional lainnya. ${ }^{36}$

Ukraina menempati wilayah strategis antara Uni Eropa, Federasi Rusia, dan wilayah Laut Hitam Turki. Aneksasi Rusia atas semenanjung Krimea pada bulan Februari dan Maret 2014 telah menjerumuskan Eropa ke dalam krisis sejak akhir Perang Dingin. Pendudukan Rusia atas Ukraina merupakan peningkatan dalam taktik Kremlin selama dua dekade terakhir untuk mempertahankan pengaruhnya di bekas Uni Soviet. ${ }^{37}$ Ukraina akan semakin terhimpit dalam kasus ini. Dalam kemiliteran terutama yang berhubungan dengan laut, lepasnya kontrol Ukraina terhadap Angkatan laut hitam Rusia di Laut Hitam akan menyebabkan Angkatan laut Ukraina semakin terdesak keberadaanya di Laut Hitam.

\footnotetext{
${ }^{33}$ Huala Adolf, Hukum Penyelesaian Sengketa Internasional (Jakarta: Sinar Grafika, 2004), 27

${ }^{34}$ Merilin Thomas, "TINJAUAN YURIDIS PENYELESAIAN SENGKETA TENTANG PENETAPAN BATAS WILAYAH LAUT NEGARA (STUDI KASUS SENGKETA WILAYAH AMBALAT ANTARA INDONESIA DENGAN MALAYSIA)", Lex et Societatis 1, no. 2 (2013): 160-168, 162-163.

${ }^{35}$ Dimitrios Triantaphyllou, "THE 'SECURITY PARADOXES' OF THE BLACK SEA REGION", Southeast European and Black Sea Studies 9, no. 3 (2009): 225-241, 225, DOI: 10.1080/14683850902934143.

${ }^{36}$ Borys Kormych, Tetiana Averochkina, Vitalii Gaverskyi, "THE UKRAINIAN PUBLIC ADMINISTRATION OF TERRITORIAL SEAS: A EUROPEAN EXAMPLE", European Energy and Environmental Law Review 29, no. 2 (2020): 26-38, 38.

${ }^{37}$ Indriana Kartini, Loc.Cit., 36.
} 
Bagi Ukraina, terpisahnya Krimea menimbulkan akibat dalam bentuk perubahan wilayah, kebijakan domestik, geopolitik dalam bentuk hilangnya properti ekonomi negara di semenanjung Krimea, memiliki sejumlah konsekuensi yang penting bagi sektor energi dan pertambangan, serta infrastruktur pelabuhan yang signifikan bagi kepentingan ekonomi Ukraina. Selain itu, muncul pula permasalahan demarkasi antara Rusia dan Ukraina itu sendiri. Perbatasan darat antara Ukraina dan Krimea membentang sejauh $20 \mathrm{~km}$ antara daerah otonom Krimea dan wilayah Kherson di Ukraina. Rusia kemungkinan akan mencoba merebut sebagian wilayah Arabat Spit, bagian dari wilayah Kherson, dan mengendalikan kompresor pipa gas yang memasok Krimea. ${ }^{38}$

Pada saat yang sama, dari sudut pandang ekonomi, dampak dari hilangnya Krimea di Ukraina mempengaruhi ekonomi makro hanya di wilayah terbatas (Krimea pada 2013 menyumbang 3,6\% dari GDP Ukraina). Namun, ini akan berdampak serius pada beberapa sektor ekonomi yang dihasilkan dari penyitaan properti Ukraina di semenanjung oleh pemerintah Krimea. Hilangnya sektor energi lokal dan aset pertambangan, termasuk Chomomornaftohaz, adalah harga yang harus dibayar oleh Ukraina. Perusahaan ini adalah salah satu dari tiga perusahaan tambang milik negara milik NAK Naftogaz dari Ukraina dan merupakan salah satu produsen gas yang tumbuh paling cepat pada tahun 2014. Namun, kerugian Ukraina sebagai akibat dari terlepasnya Chomomornaftohaz tidak secara fundamental mengubah keseimbangan gas Ukraina. ${ }^{39}$

Aneksasi Krimea berkaitan juga dengan zona ekonomi eksklusif Ukraina di Laut Hitam dan Laut Azov. Dalam praktiknya, Ukraina tidak dapat mengimplementasikan penyelesaian proyek produksi hidrokarbon di Laut Hitam untuk mendorong pasokan perusahaan-perusahaan Barat. Misalnya, pada akhir 2013, Ukraina diinstruksikan oleh ENI dan EdF untuk mengekstraksi gas dari sebuah bak di Selat Kerch; dan pada 19 Maret 2013, perusahaan Inggris Shell menarik diri dari negosiasi untuk menandatangani kontrak dalam proyek produksi hidrokarbon di wilayah Skifski di Laut Hitam. Akibat dari sisi ekonomi yang penting lainnya adalah perubahan dalam kepemilikan perusahaan swasta yang beroperasi di Krimea. Kemungkinan besar, bisnis Rusia akan berkembang dalam skala besar, tidak hanya dengan otoritas lokal. ${ }^{40}$.

Perselisihan antara Rusia dan Ukraina mengenai status hukum dan perbatasan Laut Azov dan Selat Kerch sama relevannya dengan status pangkalan Armada Laut Hitam di Sevastopol. Proses ini dipengaruhi oleh lingkungan politik saat ini terutama pihak Ukraina yang dalam posisi negosiasi yang terus berubah, tergantung pada iklim politik di Ukraina. Bagi Federasi Rusia tugas utamanya adalah melindungi kepentingan kedua belah pihak sebanyak mungkin dan mencegah internasionalisasi ruang maritim yang menguntungkan negara-negara non-regional ketiga ini. Tampaknya setelah lebih dari 30 putaran negosiasi, harapan akan adanya semacam kompromi mulai muncul ${ }^{41}$. Pengalaman Ukraina membuktikan bahwa efektivitas administrasi publik laut teritorial (juga zona ekonomi eksklusif) terkait erat dengan kemungkinan untuk menerapkan yurisdiksi negara di wilayah laut Ukraina. Selain itu, lima tahun yang telah berlalu sejak aneksasi ilegal Krimea telah menunjukkan pentingnya tindakan non-standar dan asimetris dalam penyelenggaraan laut teritorial (juga zona ekonomi eksklusif). ${ }^{42}$

\footnotetext{
${ }^{38}$ Ibid., 38.

${ }^{39}$ Loc. Cit.

${ }^{40}$ Ibid., 39.

${ }^{41}$ Pavel Gudev, "AZOV AND BLACK SEA REGION NEW POLITICAL AND LEGAL REALITIES", World Economy and International Relations 62, no. 11 (2018): 91-102, 99-100, DOI: 10.20542/0131-2227-2018-62-11-8798.

${ }^{42}$ Borys Kormych, Tetiana Averochkina, Vitalii Gaverskyi, Loc.Cit, 416.
} 


\section{Kesimpulan}

Berubahan wilayah laut Rusia di laut hitam yang sangat signifikan tentunya juga akan memberi keuntungan yang sangat besar dalam pemanfaatan zona ekonomi ekslusif yang baru ini bagi Rusia. Rusia memiliki berbagai cara yang dapat digunakan untuk meluaskan pengaruh regionalnya, seperti ekspor energi dan ikatan perdagangan. Aneksasi adalah suatu metode perolehan kedaulatan wilayah yang dipaksakan. PBB Sebagai Organisasi Internasional dapat menyelesaikan konflik antara Ukraina dan Rusia. Mahakamah Internasional (International Court of Justice) merupakan lembaga peradilan dibawah Perserikatan Bangsa-Bangsa yang mengadili sengketa internasional yang melibatkan negara. UNCLOS 1982 dapat digunakan sebagai panduan dalam penyelesaian masalah mengingat Rusia dan Ukraina telah meratifikasi UNCLOS 1982.

Bagi Ukraina, lepasnya Krimea menimbulkan beberapa konsekuensi, baik perubahan wilayahnya, politik internal, geopolitik, maupun ekonomi dalam bentuk hilangnya properti negara di semenanjung, termasuk sektor energi dan pertambangan serta infrastruktur pelabuhan yang signifikan bagi kepentingan ekonomi Ukraina. Dapat dilihat dengan adanya aneksasi Krimea kedalam Federasi Rusia akan menyebabkan banyak hal negatif bagi Ukraina. Kebutuhan Ekonomi dalam bidang ekonomi seperti Perikanan, Kebutuhan barang tambang, arus lalu lintas laut, kebutuhan Angkatan perang Ukraina, dan jalur perdagangan bagi Ukraina akan semakin terhimpit.

\section{A. Jurnal}

\section{DAFTAR PUSTAKA}

Baillie, R. "EUROPE SEEKS SECURE ENERGY SUPPLY AS RUSSIA TURNS UP HEAT", Jane's Intelligence Review 18, no. 12, 2006: 1-10.

Blockmans, Steven. "CRIMEA AND THE QUEST FOR ENERGY AND MILITARY HEGEMONY IN THE BLACK SEA REGION: GOVERNANCE GAP IN A CONTESTED GEOSTRATEGIC ZONE”, Southeast European and Black Sea Studies 15, no. 2, 2015: 179-189, DOI: 10.1080/14683857.2015.1060016

Borshchik, Natalia D., et.al. "CUSTOMS, BORDER AND QUARANTINE CONTROL BODIES OF THE CRIMEAN PENINSULA IN THE LATE 18TH - FIRST HALF OF THE 19TH CENTURY: REGULATORY FRAMEWORK AND PERSONNEL STRUCTURE", Bylye Gody 54, no. 4, 2019: 1506-1513, DOI: 10.13187/bg.2019.4.1506.

Bosbotinis, James. "ASSESSING THE STRATEGIC IMPORTANCE OF THE BLACK SEA REGION". Romanian J. Eur. Aff 10, 2010: 1-22.

Friedman, Shani. "THE CONCEPT OF ENTITLEMENT TO AN EXCLUSIVE ECONOMIC ZONE AS REFLECTED IN INTERNATIONAL JUDICIAL DECISIONS”, Israel Law Review 53, no. 1, 2020: 101-133, DOI: 10.1017/S0021223719000190.

Gudev, Pavel. "AZOV AND BLACK SEA REGION NEW POLITICAL AND LEGAL REALITIES", World Economy and International Relations 62, no. 11, 2018: 91-102, DOI: 10.20542 / 0131-2227-2018-62-11-87-98.

Kartini, Indriana. "ANEKSASI RUSIA DI KRIMEA DAN KONSEKUENSINYA BAGI UKRAINA", Jurnal Penelitian Politik 11, no. 2, 2016: 27-41, DOI: 10.14203/jpp.v11i2.199.

Kormych, Borys., et.al. "THE PUBLIC ADMINISTRATION OF TERRITORIAL SEAS: UKRAINIAN CASE", Int Environ Agreements 49, no. 6, 2020: 577-595, DOI: 10.1007/s10784-020-09473-9. 
Kormych, Borys., et.al. "THE UKRAINIAN PUBLIC ADMINISTRATION OF TERRITORIAL SEAS: A EUROPEAN EXAMPLE”, European Energy and Environmental Law Review 29, no. 2, 2020: 26-38.

Mankoff, Jeffrey. "RUSSIA'S LATEST LAND GRAB: HOW PUTIN WON CRIMEA AND LOST UKRAINE", Foreign Affairs 93, no. 3, 2014: 60-68.

Schneider, Mark B. "RUSSIA CHEATS", Air Force Magazine 99, no. 7, 2016: 38-42.

Schofield, Clive. "PARTING THE WAVES: CLAIMS TO MARITIME JURISDICTION AND THE DIVISION OF OCEAN SPACE”, Penn St. JL \& International Affair 1, no. 1, 2012: 40-58.

Thomas, Merilin. "TINJAUAN YURIDIS PENYELESAIAN SENGKETA TENTANG PENETAPAN BATAS WILAYAH LAUT NEGARA (STUDI KASUS SENGKETA WILAYAH AMBALAT ANTARA INDONESIA DENGAN MALAYSIA)", Lex et Societatis 1, no. 2, 2013: 160-168.

Triantaphyllou, Dimitrios. "THE 'SECURITY PARADOXES' OF THE BLACK SEA REGION", Southeast European and Black Sea Studies 9, no. 3, 2009: 225-241, DOI: 10.1080/14683850902934143

Trifanov, Denis. "RUSSIA BOOSTS COUNTERINSURGENCY EFFORTS IN NORTH CAUCASUS", Jane's Intelligence Review 18, no. 2, 2006: 1-98.

Yusuf, Adijaya. "PENERAPAN PRINSIP PENDUDUKAN EFEKTIF DALAM PEROLEHAN WILAYAH: PERSPEKTIF HUKUM INTERNASIONAL". Jurnal Hukum \& Pembangunan 33, no. 1, 2017: 1-15.

\section{B. Buku}

Adolf, Huala. Hukum Penyelesaian Sengketa Internasional. Jakarta: Sinar Grafika, 2004.

Goldrick, James. Grey Zone Operations and the Maritime Domain, Australian Strategic Policy. Australia: Barton ACT, 2018.

Marzuki, Peter M. Penelitian Hukum. Jakarta: Kencana Prenada Media Group, 2015.

Moleong, Lexy J. Metodologi Penelitian Kualitatif Edisi Revisi. Bandung: Remaja Rosdakarya, 2011.

Olliver, Madeline. An International Legal Analysis of Russia's Intervention in Ukraine. Disertasi.

New Zaeland: Bachelor of Law, the University of Otago, 2015.

Shaw, Malcolm N. International Law. Cambridge: Cambridge University Press, 1997.

Soekanto, Soerjono., Sri Mamudji. Penelitian Hukum Normatif. Jakarta: Raja Grafindo Persada, 2004.

Tahar, Abdul Muthalib. Zona-zona Maritim Berdasarkan Konvensi Hukum Laut 1982 dan

Perkembangan Hukum Laut Indonesia. Lampung: Penerbit Universitas Lampung, 2011.

Thontowi, Jawahir. Hukum Internasional Kontemporer. Bandung : Refika Aditama, 2006.

United Nation. Buletin Law of the Sea. Division for Ocean Affairs and the Law of the Sea Office of Legal Affairs. New York: United Nation, 2004.

\section{Internet}

https://jamestown.org/program/russian-navy-preparing-to-bottle-up-ukrainian-shipping-in-sea-ofazov, diakses pada tanggal 22 Juli 2020 pukul 14.42 WIB.

https://www.britannica.com/place/Black-Sea/Economic-aspects. Accessed 22 Juli 2020, diakses pada tanggal 16 September 2020 pukul 12.59 WIB. 
https://www.britannica.com/place/Russia, diakses pada tanggal 16 September 2020 pukul 12.59 WIB.

https://www.state.gov/r/pa/prs/ps/2018/08/285578.htm, diakses pada tanggal 22 Juli 2020, pukul 15.31 WIB. 